\title{
Business Strategy of Women Entrepreneur in Bangladesh
}

\author{
Aliya Parvin ${ }^{1,2}$ \\ ${ }^{1}$ Dapartment of Administration and Finance, Bangladesh Jute Research Institute, Dhaka, Bangladesh \\ ${ }^{2}$ Faculty of Business \& Economics, Daffodil International University, Dhaka, Bangladesh
}

Email address:

aliyabdad@yahoo.com

\section{To cite this article:}

Aliya Parvin. Business Strategy of Women Entrepreneur in Bangladesh. American Journal of Operations Management and Information Systems. Vol. 3, No. 1, 2018, pp. 22-26. doi: 10.11648/j.ajomis.20180301.13

Received: February 24, 2018; Accepted: March 13, 2018; Published: April 4, 2018

\begin{abstract}
Women's economic empowerment is an inevitable part of economic development discourse in any development undertaking of a nation. Women empowerment depends on taking part in various development activities. Therefore, the involvement of women in various entrepreneurial activities has empowered them in social, economic and cultural fields. Despite recent progress in the advancement and empowerment, women in Bangladesh still remain vulnerable to poverty and social deprivations. Women entrepreneurs are in a less favorable position compared to men in case of accessing for example commercial credit from formal financial service providers, more lucrative markets, rather than the traditional local markets, technology and information to establish and grow their businesses, national incentives in small enterprise development through gender blind private sector development and fiscal policies and legislation and training and education for small enterprise development. In such a context, this paper attempts to investigate, evaluate and analyze the available support services for developing women entrepreneurship in Bangladesh. The paper also focuses on some issues of concern and challenges of women entrepreneurship development in Bangladesh and finally, provides some strategy recommendations.
\end{abstract}

Keywords: Women Entrepreneurs, Women Entrepreneurship, Women Empowerment SME Entrepreneurs

\section{Introduction}

Contribution of women in the economy is very important for the growth of socio-economic environment of Bangladesh [1-3]. Without a meaningful and active participation of women, half of the total population, in regular economic activities, a dynamic and sustainable economy is impossible. In view of the need to bring the rural women folk in the development stream of the country, both the Government, the NGOs and other related agencies have provided ample opportunities to promote entrepreneurial skill among women. Income-generating activities, credit facilities, skill training, market opportunities have all combined to pave the way for the emergence of entrepreneurial development among women in rural Bangladesh. Bangladesh has undertaken systematic reforms across all sectors in the last decade with an emphasis on the initiatives to increase women's participation through laws, international conventions, and affirmative action's to meet quotas to ensure women's participation [4-5]. It appears that women have brought a social and economic change; and opened up a new dimension in the business area through their participation in different socio-economic activities in
Bangladesh. Women are essential part of nation's human resources. Bangladesh indicates that women comprise almost $50 \%$ of the total population [6]. Due to this demographic structure, the issue of the participation of women in the mainstream economy is imperative. Without a meaningful and active participation of women, half of the total population, in regular economic activities, a dynamic and sustainable economy is impossible. A sustainable economy is a precondition for national growth and prosperity including institutionalization of a democratic system. It is also impossible to achieve the target of a poverty-free society without incorporation of women in the mainstream economy. Women's economic empowerment is an inevitable part of development discourse. Excluding women from the mainstream development program, institutionalization of a sustainable development process is just unthinkable. It is inspiring to mention here that a new woman's entrepreneurs' class is increasingly emerging each year taking on the challenge to work in a male-dominated, competitive and complex economic and business environment [7]. Bangladesh is a resource-limited and overpopulated country where society is highly stratified, services and opportunities are determined by gender, class and 
location. However, women make nearly half of the population which means huge potential to be utilized for socio-economic development of the country. Development and enrichment of women entrepreneurship are the means of promoting national competitiveness and sustainability. Its represent the individual and community level initiative and contribution towards the greater national economy, poverty alleviation models pursued by both the GOs and NGOs consider the above mentioned phenomenon as one of the prior sector of intervention. Bangladesh is one of the countries, which rectified the UN Convention on the Elimination of all Forms of Discrimination against Women (CEDAW). SME entrepreneurship is a vital sector to emphasize by the concerns to develop the women in contributing the individual, national and thus international arena[8-10]. The Government has formed a National Women Small and Medium Enterprise (SME) Forum under the SME Foundation of the Ministry of Industry to promote women's participation in formal economic sectors. Bangladesh's Poverty Reduction Strategy Paper (PRSP), which is now the main document for Bangladesh's national development, also incorporated some noteworthy issues to ensure women's participation in social and economic life. The industrial and SME policies of 2005 have emphasized women entrepreneurship development, particularly in the SME sector [7]. Government of Bangladesh has identified 32 thrust sectors and thus has been formulating policies for development [11].

Objectives of the Study

The purpose of the study is to investigate the available support services of women entrepreneurship to ensure its growth and development in Bangladesh. To achieve this objective the following specific objectives are outlined:

a) To study the available support services of women entrepreneurs in Bangladesh.

b) To explore the constraints and challenges faced by women entrepreneurs.

c) To suggest some policy recommendations to overcome these constraints.

\section{Methodology of the Study}

In light of the objectives of the study, the paper has been designed to illustrate the available support services as well as their impact and effectiveness of women entrepreneurship in Bangladesh. To this end an extensive literature survey has been conducted. The study is based largely on secondary data from published sources including websites of different organizations. Data and information from secondary sources were collected from different libraries, Universities, Journals. As for example, Asian Development Bank, International Labor Organization, Bank of Small Industries and Commerce, Bangladesh Bureau of Statistics etc.

\section{Findings and Discussions}

\subsection{Women Employment Status: Data}

Women in Bangladesh are employed in low category of jobs. Most of them are employed in Agriculture, Forestry and Fishery sector, where the share of the women employees is $78.8 \%$. Even in clerical job women are poorly represented. In administrative function, there is little woman participation, which clearly shows the frustrating job situation for the women in Bangladesh. Due to the grace of the emerge and growth of the Ready Made Garments sector, the share of women in production has increased; the share of women in production sector is $10 \%$. Only in "sale" sector, the job share of women is more than their male colleagues, the share of women in this sector is $5.4 \%$ whereas the male only $2.4 \%$ of the jobs of this category [12]. The entrepreneurship status of the population shows that out of $46.8 \%$ self employed citizen, women make only $8.3 \%$. The situation is, however, in urban Bangladesh a little better. In urban area nearly $15.4 \%$ of the $36.7 \%$ self-employed people are women. In rural area, it is only $7.4 \%$ of $47.6 \%$. Most of the women are unpaid family helper, $83.2 \%$ in rural area and $42.9 \%$ in urban area. A part of the poor women works also as day labourer. On national level it is $5.7 \%$, in urban area $6.2 \%$ and in rural area $5.6 \%$ [12]. This shows that industrial development in Bangladesh is unable to absorb even the cheapest part of the labour force - the women labour. Previously, women's enterprises were confined in sectors that were dominated by traditional gender role, such as food and beverage, beauty parlour, health, education, webbing, tailoring and wholesale and retail apparel trade. But the situation is improving slowly; today women are also in occupations, which were solely controlled by the male before. Now, some of them possess top management post in private and public sector enterprises, sit in the most important policy making bodies of the country, are entrepreneurs and own enterprises. Women are now seen also as owners and managers of cold storage, shipping lines, advertising firms, travel agencies, interior decoration, engineering workshops and even garment industries, etc.

\subsection{Support Services for Women Entrepreneurs in Bangladesh}

The importance of women entrepreneurs in the national development process has been acknowledged by successive governments and steps initiated to realize these objectives. There are following specific areas where women entrepreneurs need supportive assistance:

a) Legal assistance includes transparent regulation for getting Trade license etc. as well as other processes.

b) Financing helps to reduce interest rate, easy access to loan, and Guarantor free loan for women entrepreneurs.

c) Marketing assistance should be built among people to use local products and market should be created abroad through fair and other promotional campaigns.

d) Technology includes continuous product/service quality control, quality enhancement through adopting new technology, tax reduction on imported new machinery etc.

e) Business management includes a range of activities like HR, employee handling, customer management, record keeping, costing, inventory management, procurement, strategic positioning and so on. 
The support services provided by various financial and credit institutions as well as by some public and private institutions have been examined in this section.

\subsection{Policies and Programs Encouraging Supporting Women Entrepreneurs}

The Government has acknowledged the importance of mainstreaming women in the national development process, and has initiated steps towards realizing this objective. Consequently, under successive Five Year Plans, the Ministry of Women's and Children's Affairs and other line ministries took up appropriate programs and projects under the coverage of sectoral allocations. In the Fifth Five Year Plan (1997-2002) as many as 24 goals and objectives are set for development of women and children in the country. The Government of Bangladeshhas set distinct strategies in its National Action Plan (NAP) for the development of the women entrepreneurship:

a) Adoption of a comprehensive sustainable industrial policy that will promote equity for women and men;

b) Ensure women's easy access to markets;

c) Develop entrepreneurial skills of the women;

d) Provide infrastructure facilities for women entrepreneurs;

e) Support research, evaluation and action oriented programs of industry particularly for women engaged in the industrial sector.

The SME Foundation has been recommended a gender action plan in September 2007. The Gender Action Plan (2008-2012) extended business support services towards SME women entrepreneurs by following activities:

a) Organize National and International trade fair for women entrepreneurs.

b) Advocate for insurance facilities for SME.

c) Advocate for reducing custom and excise duties for SME women entrepreneurs.

These goals and objectives, if implemented properly will definitely contribute with the participation of women in every sphere of our national life.

The Government of Bangladesh's Industrial Policy 2005 stipulates several useful strategies under micro level preparation to broaden the participation of women entrepreneurs, such as:

a) Identifying women entrepreneurs capable of running independent and businesses.

b) Designing various incentive packages.

c) Reserving plots for women entrepreneurs in industrial parks in all divisional towns.

d) Ensuring participation of women entrepreneurs in policymaking, financing, and investment.

e) Giving pre-investment advice and assistance.

f) Establishing a separate bank to ensure easy access to industrial credit, equity capital, venture capital, and working capital, collateral free loans.

g) Providing financial support and in cases arranging necessary capital.

\subsection{Export Promotion Strategy Paper 2006-2009 Has Been Outlined a Number of Strategies}

a) Promoting labor-intensive (especially female labor) export-oriented production.

b) Encouraging female entrepreneurs in the export sector.

c) Encouraging them invent new production and product diversification.

d) Honoring best female entrepreneurs by awarding Annual Export Trophy.

Some other important policies taken by the Government are enumerated as follows:

\subsection{Supporting Services of Financial and Credit Institutions}

Generally, financial institutions and banks extend credit for women under micro-credit program for poverty reduction. The interest rates of these credit vary based on the cost of the fund. For this purpose, mainly donor supported project funds are used, though some funds are also provided by Bangladesh Bank. The Bangladesh Bank directs the commercial banks to lend at least 15 percent of their lending capital for the industrial sector, while 5 percent are expected to be spent for the small scale industry (SCI) sector. Furthermore, as pointed out by an updated paper by the Dhaka Chamber of Commerce and Industry (DCCI) (p. 10), other than for poverty reduction project loan, there is no special regulation for credit for women entrepreneurs. These loans are often operated through NGOs or development agencies. Men mainly access the investment in the industrial sector. Some banks have ladies branches. But the objective of the activities is to mobilize savings and not encourage investments. Most of these branches incur loss, because they function as deposit collectors rather than lending institutions.

\subsection{Impact and Effectiveness of Current Support Services}

Credit-based self-employment programs undertaken by both government agencies and NGOs have proliferated rapidly. A study conducted by Special Employment Creation Schemes (SECS) on 140 organizations indicates that, despite this rapid increase, total coverage remains small to meet the extent of poverty needing attention. Research into the major SECS shows that less than 5 per cent of the target population are covered [13]. Since a large number of borrowers receive repeat loans, the net additional increase in self-employment could even be much smaller. Furthermore, even though reports indicate improvements in income and living standards among targeted households, many of these families remain below the poverty threshold. Thus the impact of current support services taken by the Government and NGOs are not praiseworthy for ensuring rapid growth of women entrepreneurship development. A study indicates that support services have had some positive effect on the growth of small firms [14]. It shows a significantly higher performance by assisted firms than similar non-assisted enterprises.Ideally, programs should be home-grown and driven by Bangladeshi perceptions of what is needed, rather than being excessively donor driven, as is now the case with most government programs [15]. 


\subsection{Constraints and Some Challenges Faced by Women Entrepreneurs in Bangladesh}

There are a number of constraints faced by women entrepreneurs in Bangladesh as summarized in following categories:

Gender specific constrains: Women entrepreneurs face some constraints due to the gendered access to resources that has been added a new dimension of difficulties for women entrepreneurs. The following figure explains the issue of gender and how this has an immediate influence on access to resources:

Access to finance: In South Asia, women are almost invisible to formal financial institutions- they receive less than 10 percent of commercial credits [16]. "Seed Working Paper No. 14", by Nilufer Ahmed Karim made forILO was based on the findings of the most comprehensive study done till the date with a sample size of 500 entrepreneurs (374 women and 126 male). $6 \%$ got loans from family members, $0.5 \%$ got loans from commercial banks. $0.3 \%$ got loans from national banks, $61 \%$ got loans from NGOs [17]. About 43\% of women entrepreneurs are not aware of credit facilities granted to women entrepreneurs. Inadequate financing was ranked first by $76 \%$ of women entrepreneur (92\% rural and $69 \%$ urban).

Access to financial institutions: Rural women entrepreneurs face considerable hardships in accessing finance. Because, they are outside the radar of formal financial institutions, despite several Government instructions to open up for the marginal clients.

Lack of awareness of facilities and support services: Women entrepreneurs in rural area are unaware of available support services and the procedures for getting it. Mechanisms for disseminating information on investment opportunities and the types and sources of assistance available are inadequate [18].

Lack of institutional support facilities:Different public institutions in Bangladesh are characterized by corruption, large-scale inefficiencies, lack of initiative, and ineffective decision-making (ADB 1997). Banks, furthermore, are not structured in such a way as to reach a target clientele without capital or assets [17].

Lack of social capital: Due to lack of social capital, poor people at the rural area do not have the social networks and this deprives the target groups of a key linkage with business partners which could otherwise have provided valuable assistance regarding different aspects of business development.

\section{Conclusion and Policy Recommendations}

Entrepreneurship is the key to the creation of new enterprises that energize and revitalize the economy. Entrepreneurship serves as the catalyst in the process of industrialization and economic growth. Women entrepreneurs can play a vital role in combating rural poverty. The emergence and development of women entrepreneurship largely depends on the supporting conditions of different factors such as economic, social, cultural, and psychological. To improve the socio-economic status of the women in Bangladesh it is necessary to formulate appropriate policies, take necessary actions and introduce effective measures to integrate the women in the mainstream of the development process. Therefore, the following recommendations may be considered worthwhile:

(i) Financial Policies and Strategies: In respect of the policy, strategy and function of Bangladesh Bank and Commercial Banks following recommendations may be made:

a) Identification of viable women entrepreneurs.

b) Establishing credit guarantee scheme for women entrepreneurs.

c) Sinking interest rate for loans for women entrepreneurs.

d) Setting up special window for financing women entrepreneurs.

e) Pre- and post investment counseling for women entrepreneurs for credit.

f) Allocation of women share in equity development and fund.

g) Preferential treatment of the women entrepreneurs by credit in thrust sectors.

h) Monitoring of credit disbursement for women entrepreneurs.

i) Maintaining gender based data on credit disbursement and dissemination information on credit opportunities.

j) One stop service should be created in the Commerce Ministry exclusively for the women entrepreneurs for facilitating investment and business.

k) Establishing a women bank.

1) Enabling credit for the women without collateral.

(ii) Counseling and support services:There are following counseling and support services to facilitate women entrepreneurship in Bangladesh:

a) Credit programs need to be linked with entrepreneurship development training programs.

b) Lending procedures must be simplified, with minimum documentation formalities.

c) Special provisions should be made for female entrepreneurs.

(iii) Other Suggestions: There are following other recommendations for facilitating women entrepreneurship:

a) Tax holiday for women entrepreneurs should extended further and made more supportive for them.

b) Gift Tax should be dismantled in the case of women beneficiaries.

c) Either the registration procedure for import and export business should be simplified and made women friendly or completely dismantled.

d) All anomalies in custom procedure must be removed and women friendly.

e) Tariff for women entrepreneurs should be abolished.

f) Value Added Tax (VAT) for women entrepreneurs should be abolished.

Therefore, Government and private sector interventions have generally accelerated income generating activities of women both in the urban and rural areas with entrepreneurship 
development. Such kind of support services, policies, and strategies help to change the scenario of Bangladesh especially for the women who have gathered courage to break barriers and enter the off-house working force as entrepreneurs and workers - a situation not appropriate for women or accepted by the society in the past.

\section{References}

[1] ADB, (1997), North-West Area Development Study Project, ADB TA No. 2545 (Bangladesh).

[2] Ahmed, S. \& Sikder, Z.H., (1997), Women in Small Business of Bangladesh: A Study on Some Selected Business Firms in Greater Chittagong, The Chittagong University Studies, Commerce Vol- 13, p. 41-54.

[3] Chowdhury, Masuda M. Rashid,(2001), The Emerging Women Entrepreneurs of Bangladesh,the FBCCI Journal, Volume $2(5-6)$.

[4] Sultana, T. \&Uddin, M.J., (2004), Role of Women in Service Sector: A Study on Education Sector in Chittagong, The Chittagong University Journal of Business Administration, Vol- 19, p. 149-161.

[5] GroundWork, (2002), Bangladesh Education Sector Review, Report No-2, Overview of the status of the Gender Equity, GroundWork, Inc, 1825 Eye Street, N.W., Suite 400, Washington, D.C. 2002

[6] BBS (2006). Bangladesh Bureau of Statistics, Statistical Division, Ministry of planning,Government of the People's Republic of Bangladesh.

[7] Bangladesh Women Chamber of Commerce and Industry (BWCCI) 2008, P: 19.

[8] Morshed, Syeda F., (2008), Challenges and opportunities for women SMEs in Bangladesh, 2ndNational SME Women Entrepreneurs Conference on Empowering Women Entrepreneurs Towards a Shared Economic Growth, SME Foundation, Dhaka.

[9] Saleh, A., (1995), A Profile of the Women Entrepreneurship in Bangladesh, Journal of Business Studies (Dhaka University), Vol. 16(1):159-170.

[10] HabiburRahman, A. H. M., (1995), Bank Credit for Women Entrepreneurship Development in Bangladesh, Bank Parikrama, Vol. 20, p. 67.

[11] Raihan, S and Haque, A. K. Iftekharul (2009), "A Critical Observation on Some Major Governmental Policies", Bangladesh Economic Outlook, Vol. 2, No. 2, p. 7.

[12] BBS (2009). Bangladesh Bureau of Statistics, Statistical Division, Ministry of planning,Government of the People's Republic of Bangladesh.

[13] UNDP, 1993. Towards an integrated employment promotion and poverty alleviation report of amission (Bangladesh).

[14] Sarder,J.H. (1995), Small enterprise development in Bangladesh. Unpublished Ph.D.dissertation, University of Stirling.

[15] Hye, H.A., (1996), Below the line: Rural poverty in Bangladesh, Dhaka, the University Press Ltd.

[16] Haq, M., (2000), Human Developmentin South Asia: The Gender Question, Human Development Centre, Oxford University Press.

[17] Karim, Nilufer, A. (1995), Women entrepreneurs and credit financing in Bangladesh, Bank Parikrama, Vol. 20(1-2):80-94.

[18] Karim, Nilufer A., (2001), SEED Working Paper No. 14, Jobs, Gender and Small Enterprises in Bangladesh: Factors Affecting Women Entrepreneurs in Small and Cottage Industries in Bangladesh, International Labour Office, Geneva. 